\title{
Next-generation sequencing at Merck-Boston
}

\author{
Richard Stevens \\ From Beyond the Genome 2012 \\ Boston, MA, USA. 27-29 September 2012
}

\begin{abstract}
Next-generation sequencing (NGS) is quickly replacing other methods for determining expression profiling of RNA as well as single-nucleotide variations within the genomes of both model organisms and human samples. At the Boston facility of Merck Research Laboratories, we concentrate on preparation and sequencing of samples where the research needs cannot be met by commercial venders. These unmet needs may be due to either availability of up-to-date protocols or to deadline constraints. In addition to validating and developing new libraryconstruction and sequencing protocols, we also evaluate commercial vendors in consideration for future outsourcing. One of these current projects is an evaluation of transcriptome sequencing and profiling of formalin fixed paraffin embedded (FFPE) samples from Merck's current and past clinical studies. FFPE samples are readily available and easily stored but create difficulties in NGS analysis due to the low quality of the purified nucleic acids. Here, we compare techniques for transcriptome sequencing to microarray profiling of RNA purified from FFPE tissues as well as their mirrored fresh frozen counterparts.
\end{abstract}

Published: 1 October 2012

doi:10.1186/1753-6561-6-S6-P36

Cite this article as: Stevens: Next-generation sequencing at Merck-

Boston. BMC Proceedings 2012 6(Suppl 6):P36.

Submit your next manuscript to BioMed Central and take full advantage of:

- Convenient online submission

- Thorough peer review

- No space constraints or color figure charges

- Immediate publication on acceptance

- Inclusion in PubMed, CAS, Scopus and Google Scholar

- Research which is freely available for redistribution 